Article

\title{
Chinese State-Owned Enterprise Investment in Mekong Hydropower: Political and Economic Drivers and Their Implications across the Water, Energy, Food Nexus
}

\author{
Nathanial Matthews ${ }^{1, *}$ and Stew Motta ${ }^{2}$ \\ 1 CGIAR Research Program on Water, Land and Ecosystems, Colombo 10120, Sri Lanka \\ 2 CGIAR Research Program on Water, Land and Ecosystems, Vientiane 01000, Lao PDR; \\ E-Mail: stewart.motta@gmail.com \\ * Author to whom correspondence should be addressed; E-Mail: n.matthews@cgiar.org; \\ Tel.: +94-11-288-0000.
}

Academic Editors: Marko Keskinen, Shokhrukh Jalilov and Olli Varis

Received: 18 May 2015 / Accepted: 26 October 2015 / Published: 6 November 2015

\begin{abstract}
Over the last decade, Chinese State-Owned Enterprises have emerged as among the most active investors in Mekong Basin hydropower development. This paper uses a political economy analysis to examine the forces that drive Chinese State-Owned Enterprises to invest in hydropower in the Mekong Basin. We focus our analysis on the Lancang (Upper Mekong River) in China and in the Greater Mekong Subregion (GMS), with an emphasis on Cambodia. The analysis reveals how powerful political and economic forces from within China and the GMS influence the pace, location and scale of investments in hydropower. These forces include foreign exchange reserves, trade packages and foreign direct investment, and political alliances. Combining the political economy and nexus approaches, we conclude that although policies from China recognize interconnections across the nexus, political and economic forces craft narratives that downplay or disregard these nexus interconnections and trade-offs. This in turn, influences how trade-offs and interconnections in hydropower development are managed and recognized in both local and transboundary contexts, thereby, creating potentially significant negative impacts on livelihoods, food security and the environment.
\end{abstract}

Keywords: China; state-owned enterprise; hydropower; water-energy-food nexus; greater mekong subregion; political economy; transboundary 


\section{Introduction}

This paper examines the political and economic drivers surrounding Chinese State-Owned Enterprises' (SOE) activities in Mekong Basin hydropower, and the implications of these forces across the water, energy and food nexus, hereafter the nexus. The interconnections between water, energy and food have more recently been grouped together as "the nexus" [1-3]. Policy makers, international organizations, NGOs, academics and farmers, however, have been grappling with how to manage the interdependencies and trade-offs in the development of natural resources and transboundary rivers for decades [4,5]. One value of the nexus perspective is that it focuses attention on the interdependencies, choke points and trade-offs, thereby helping to understand leverage points and possible solutions [1-3].

The nexus concept takes on different manifestations depending on the context, scale and geography where it is examined [1-3]. For the purpose of this paper, we analyze the nexus between rivers (water), hydropower development (energy), and fish (food). Hydropower dams in the Mekong Basin provide an ideal case study to unpack nexus connections, interdependencies and trade-offs. Although the direct benefits of dams in the Mekong are often disputed, they are regarded by many states as a reliable and cheap source of electricity, and an important revenue stream [6]. There have also been well documented socioeconomic and environmental impacts that revolve around fisheries' losses, which are a key source of food security and livelihoods for millions of people [7].

Smajgl and Ward [8] provide a detailed assessment of how development-directed investments in the wider Mekong Region impact across water, energy and food. Keskinen et al., (this issue) also demonstrate nexus connections in the Mekong by showing how hydropower will impact the region's annual floods, thereby affecting the flood-pulse of Tonle Sap, which will likely cause degradation of fisheries. In this paper, we aim to provide a link to these studies and others by illuminating the political and economic drivers of hydropower in order to better understand why some dams are built despite their well-known impacts at both transboundary and local scales. We demonstrate that the pace of Chinese SOEs' involvement in hydropower construction and the location of investments is heavily influenced by powerful political and economic forces. These forces emerge from both within China and the Greater Mekong Subregion (GMS). We argue that although China purports to recognize nexus interdependencies and trade-offs in its policies, the political and economic forces that drive Chinese SOEs' to build hydropower dams in the GMS Basin offer little space for the consideration of their impacts across the nexus. In this way, the political and economic realities in which hydropower is developed, and in which SOEs operate in the Mekong, often recreate and entrench the original silo approaches to development that nexus policies and dialogues are aiming to address.

The remainder of the paper is divided into four sections. Section 2 provides a brief overview of the methods used in the study, and of the political economy approach. Section 3 highlights the growth of renewable energy in China. This section also examines the policies and actions that are being deployed to respond to the challenges created by rapid economic growth that is driving Chinese SOEs' involvement along the Lancang-Mekong and in the GMS. The Lancang-Mekong is chosen because it is a transboundary river undergoing rapid hydropower development by SOEs. This section additionally critically examines the "win-win" narratives that emerge from China and SOEs surrounding hydropower development on the Lancang-Mekong. These narratives frame or ignore risks and uncertainties across the nexus in ways that buttress and endorse central, top down decision-making and the agendas of powerful 
actors. Section 4 examines the political and economic drivers of Chinese SOEs' rapid development of hydropower projects throughout the GMS with a focus on Cambodia and the implications of this development across the nexus. Cambodia is chosen as a focus because it is one of China's key allies in the GMS and increasingly a destination for Chinese investment. Finally, Section 5 concludes by reviewing how political and economic factors have shaped the application of nexus policies in the GMS and the negative implications this has had and will potentially have on water, energy and food.

\section{Method}

This paper uses a broad global political economy approach to analyze the key political and economic forces that drive and shape the ways water, food and energy are managed by Chinese SOE in hydropower development in the Mekong Basin. This political economy approach helps to explore the constellation of interests, motivations and histories that shape the institutions, governance and contestations across the nexus.

Political economy has been usefully employed to analyze or compliment nexus issues and approaches at varying scales. Allouche et al. [2], for example, highlight the importance of political economy considerations when examining nexus issues by arguing that the nexus does not adequately engage with the global political economy of energy and food. They argue that policy documents tend to promote economic and technological solutions that ignore the inequalities across the political economy. The nexus' recognition of trade-offs may also be used by decision-makers to justify negative environmental impacts as an unavoidable cost to ensuring water, food and energy security. Foran [9] recognizes the need for "more vigorous thinking around the political economy of energy, water and food". Using a political economy approach coupled with historical and institutional analysis helps to uncover how power and inequality play out in the nexus [9]. Dupar and Oates [10] also use global political economy considerations to argue that the nexus approach must take account of rights-based approaches and transparent negotiation to ensure that resources are not commodified in ways that justify ignoring the environmental costs of their consumption. The importance of rights-based approaches including transparency, participation and fair negotiation in the Mekong setting has been well documented [11-13].

Political economy has also been used at more regional and local scales to examine nexus trade-offs and drivers. Middleton and Allen [14] use a political economy lens to demonstrate that the politics inherent in the nexus require that nexus approaches must consider both bottom-up analysis as well as historical, political and economic frames in order to understand the drivers and distribution of trade-offs. Political economy analysis of nexus issues is also complimented by an environmental justice lens [13]. Environmental justice helps to draw attention to the winners and losers of trade-offs. As we examine below, hydropower narratives that are driven by political and economic forces can strengthen powerful actors while excluding other stakeholders such as local people and the environment.

Political economy analysis helps to illuminate the power and economics embedded within water management and hydropower development. Mitchell's [15] analysis of the political economy of Mekong Basin development focuses on the political aspects of decision making and how the benefits and impacts of decisions have uneven distributions. Importantly, Mitchell identified the emergence of conflict between basin-wide coordination, promoted by the MRC (Mekong River Commission) and its donors, and the individual national agendas. As will be explored in this paper, this conflict continues today and 
is shaped by Chinese SOE investment. Political economy can also help to highlight the different manifestations of the nexus. Verhoeven's [16] analysis of the nexus in the highly political transboundary Nile context reminds us that the nexus is a human construct and the interconnections within it are understood in a multitude of ways and scales by different social and ethnic groups across societies, and this can result in contestation between the nexus components.

In addition to the political economy approach and a broad literature review, this paper draws from 25 informal interviews carried out from 2012 to 2014. The authors used both elite and normal interviewing to triangulate data with literature reviews and observation. Interviewees were identified by their prominent positions within organizations relevant to hydropower development and nexus issues. Interviews included senior and junior policy makers, employees of Chinese SOEs, bureaucrats, consultants, NGO staff and academics. The interview type was semi-structured using small sets of open ended questions. The questions focused around case studies and key events associated with nexus issues specifically linked to Chinese SOEs and hydropower development. The majority of interviews were carried out face-to-face in the Mekong Region, with some conducted by telephone and Skype. Several interviewees were interviewed multiple times. English was used for the majority of interviews, but some interviews and clarifying questions were done in Mandarin.

The authors take note that there are many different configurations of SOEs from China involved in hydropower development in the Mekong Basin and each have their own characteristics. We do not wish to brand all these SOEs or the Chinese government as always disregarding or downplaying the impacts of their investments and activities across the nexus. Rather, we are aiming to provide some insights into the forces that shape Chinese SOEs' decision-making and subsequent involvement in hydropower across the Basin. Our hope is that these insights might provide lessons for understanding the implications of hydropower investment in other regions. Throughout the article, we use the word China to refer to the Chinese government in a broad sense and Chinese SOEs to refer to the larger SOE hydropower developers that are representative of the main developers in the Basin. We have intentionally avoided naming many of the SOEs that we studied in this research in order to avoid any attribution to the people we interviewed. Where information came primarily from literature reviews we mention specific SOEs by name, but this does not indicate that these are the only SOEs to which the findings apply. Finally, it is worth noting that this paper focuses mainly on qualitative analysis because hydropower is deeply entwined with politics, economics and security issues across the nexus.

\section{The Nexus, Hydropower and Chinese SOEs' Activities on the Lancang-Mekong}

The Chinese government is well aware of the need to balance the trade-offs in the nexus as clearly shown by the first paragraph from the main targets of the 12th Five Year Plan (FYP):

We will maintain farmland reserves at 1.818 billion mu (approximately 121,260,600 hectares). We will cut water consumption per unit of value-added industrial output by $30 \%$, and increase the water efficiency coefficient in agricultural irrigation to 0.53. Non-fossil fuel resources will rise to $11.4 \%$ of primary energy consumption. Energy consumption per unit of Gross Domestic Product (GDP) will decrease $16 \%$ and $\mathrm{CO}_{2}$ emissions per unit of GDP will decrease 17\% [17]. 
While China has policies that attempt to address all three aspects of the nexus, a significant focus of its policies are on energy $[17,18]$. This is primarily due to China's prioritization of unimpeded economic growth, which is currently dependent on energy intensive industries. Stresses on water and food security due to air, water, and soil pollution are all viewed within the context of emissions from energy intensive industries, and constitute concerns shared by both domestic and international communities [17,18].

China's Ministry of Environmental Protection was not given ministerial level status until 2007, and remains comparatively weak. The environmental and climate policies that do exist can be seen more as by-products of China's energy security worries. Energy security worries are also linked to concerns over social unrest due to widespread and persistent environmental degradation including air quality issues in the capital, and the policy responses to address these concerns initiated under the Hu Jintao administration [19]. China's ability to meet energy demands domestically is further threatened by the agricultural and industrial sectors' massive water and energy demands [20]. The energy intensive economy has also propelled China to become the world's leading carbon emitter, which increasingly places pressure on China's administration to play a more leading role in climate change goals as an emergent superpower within the context of global geopolitics.

Environmental policies and pollutant regulation may be viewed as an obstacle and a nuisance to development in China. This is especially true at the local levels where officials are valued and promoted primarily based on GDP increases. Renewable energy, however, is a priority pillar industry for the government's national development plan [21]. Renewable energy and especially hydropower is seen by Chinese scholars and the government not as an impediment to development, but as a solution to the challenges it faces across the nexus and is the dominant goal of energy security [21]. In addition, renewable energy is perceived as an important sector for China's economic expansion, trade, and technological enhancement [22].

While there have been massive investments into all three main sources of renewable energy in China (hydropower, wind and solar), many of the investments are geared towards GDP increases at the local and corporate levels, and lack the planning and collaboration necessary to contribute effectively to the country's macro-economic targets. Despite China being the world's largest investor in wind and solar power, $23 \%$ of the turbines and $28 \%$ of the panels are not connected to the grid, and therefore do not actually contribute to national power production [23]. If around a quarter of the billions of dollars of renewable energy projects are not actually contributing energy to the grid, it may be argued that these industries are not being driven by environmental policy alone. Although policy might be aimed at energy security, the investment does not necessarily contribute to the expected energy goals, an argument that this article will return to with regards to the Mekong Basin.

China has been unable to shift its economy to less energy intensive production higher up the value chain, which will make it increasingly difficult for renewable energy targets to be met. The renewable energy sector only contributed to around 1\% of China's total energy consumption (not including hydropower) in 2010. Renewable energy is projected to contribute $15 \%$ of the energy supply by 2020 (See Table 1). Although there has been large investment in the solar and wind sectors, China's inability to shift the economy to less energy intensive production means that wind and solar energy will contribute only minimally to the overall energy supply. The vast majority of renewable energy supply that is needed to meet China's energy targets will come from hydropower production. The majority of which exists in the west and southwest of China on transboundary rivers. 
Table 1. Key energy targets enacted in China's 12th FYP (2011-2015).

\begin{tabular}{ccccc}
\hline Energy & 2010 Target & 2010 Realized & 2015 Target & 2020 Target \\
\hline Hydropower & 190 & 272.6 & 290 & 420 \\
Non-fossil fuel share in energy supply & $10 \%$ & $9.4 \%$ & $11.4 \%$ & $15 \%$ \\
Non-fossil fuel share in energy supply (excluding hydropower) & $1 \%$ & $1.2 \%$ & Unknown & $3 \%$ \\
\hline
\end{tabular}

Source: FYP 2012 [17].

China's domestic hydropower expansion strategy is partially a response designed to alleviate the current stressors across the nexus. To legitimize this strategy, the Chinese government and its SOEs have employed a number of domestic and regional narratives that couch the impacts of hydropower on the transboundary Lancang River as a "win-win" for both China and the GMS [24]. These narratives have been developed and employed over decades of domestic dam construction [24]. For example, the Chinese government has couched its rigid policy stance on hydropower in a rhetoric of regional "peace", highlighting the "win-win" outcomes for downstream riparian states [24,25]. Although China still rarely discusses the negative impacts of dams and their consequences within the nexus, it has recently been visibly more communicative with the Lower Basin states such as Thailand, Laos, Cambodia and Vietnam through the MRC [26].

Liebman [27] argues that in communicating with the GMS, China has used narratives that frame the benefits of hydropower as being shared between governments to avoid appearing as a hegemon within the region. Examples of this position can be seen in Chinese political speeches. During a speech at the MRC in 2010, H.E. Song Tao, Vice Minister of Foreign Affairs of the People's Republic of China stated that "hydropower development of the Lancang River can improve navigation conditions and help with flood prevention, drought relief and farmland irrigation of the lower reaches" and that dam construction would include "equal consultation, stronger cooperation, mutual benefit and common development" [28]. The speech made no mention of trade-offs across the nexus or how impacts would be mitigated.

In contrast to these narratives, studies show that China's cascade of dams on the Lancang is having a significant transboundary impact downstream by impeding vital sediment flows and reducing water levels by as much as 30\% during the rainy season [29]. By ignoring or downplaying the fact that all energy production has trade-offs and that in the Mekong these are potentially significant and transboundary in nature, these narratives reinforce and empower decision-making that ignores nexus connections. These narratives not only legitimize silo decision-making, they also delegitimize civil society and environmental groups who attempt to place a grounded environmental justice lens into the nexus to speak for and illuminate who wins and loses from trade-offs [13]. As we will examine next, these narratives and political and economic drivers of Chinese SOEs' hydropower development extend past China's border into the GMS. We argue that the Chinese state is using its political and economic power to reshape science to legitimize its policy agendas and international and domestic strategies. This strategy and the political and economic forces that drive it has important implications for how SOEs address the trade-offs of hydropower development in both local and transboundary contexts. SOEs are able to use the ambiguous and contested discourses surrounding the nexus to further their political and economic interests, while disadvantaged actors are continually marginalized [9]. 


\section{Chinese SOE Hydropower Expansion in the Greater Mekong Subregion and its Implications across the Nexus}

The GMS is currently experiencing a surge in hydropower development, with more than 50 on-going large-scale dam projects (over $50 \mathrm{MW}$ ) being built and managed by Chinese companies, and many more in the proposal phase [30]. The distribution of large-scale Chinese dams in the region is as follows: Myanmar 30, Lao PDR 13, Cambodia 7, Vietnam 3, and Thailand with some Chinese dam projects, but none over $50 \mathrm{MW}$ [30]. These projects are financed, developed, constructed, and contracted out primarily to Chinese SOEs. Sinohydro plays at least one of these roles in $30 \%$ of the large dam projects in the LMB, and handles the entirety of financing, developing, and building of five of the 13 large Chinese dams in the Lao PDR [30]. Large SOEs like Sinohydro often have higher capacity, scalability, greater political backing, more experience gained from domestic construction projects, and can usually build dams at a lower price than their competitors [31]. These large-scale projects usually require approval from the highest levels of government in both Beijing and in the LMB nations, and thus connections with the state serve as an asset. In the LMB, almost every major dam project has SOE involvement from well-known large enterprises, but Myanmar shows some contrast with much smaller and less well-known provincial level SOEs [30].

Beijing originally pushed its SOEs to go abroad and invest through the "Going Global Policy", which was proposed at the 5th plenary session of the 15 th central committee in 2000 . This policy acts as a roadmap for Chinese foreign investment. The ambitions of this policy were not articulated until the following FYP in 2005, when the Ministry of Foreign Trade and Economic Cooperation (MOFCOM), National Development and Reform Commission (NDRC) and Export-Import Bank of China policies began streamlining the process for investment to reach overseas markets [32]. From 2001 to 2005, China's ODI was $\$ 22.3$ billion USD in total. As part of this policy, ODI rapidly increased to $\$ 18.7$ billion USD in 2007 alone, $\$ 87.8$ billion in 2012, \$90.17 billion in 2013 and reaching a staggering \$102.89 billion in 2014 [32-35].

China's "Going Global" strategy does not simply pertain to SOEs. China's overseas investments, trade, and aid must be viewed as a package rather than separate initiatives. ODI provides a conduit for China to invest its vast capital supplies and at the same time develop strategic partnerships and secure access to resources. Urban et al. [30] describe how these elements are packaged together in hydropower deals in the GMS:

The Chinese practice is hence often to bundle aid, trade and investment by providing, for example, both investments and concessional loans for dam building and linking this to the export of electricity coupled with the import of Chinese manufactured goods and trade deals for Chinese firms [30].

One example of this ODI policy, related to hydropower, is the Kamchay Dam in Cambodia, which was the first Build Operate Transfer (BOT) hydropower project in the country. Sinohydro is the primary SOE involved in the construction and operation of the Kamchay Dam project. The $\$ 280$ million that was required to construct the dam, however, was part of a $\$ 600$ million aid package given to Cambodia by China in 2006 [36]. 
Chinese investment in hydroelectric development in the GMS has expanded rapidly in the past decade. McNally et al. [37] argue that this investment should also be understood as exporting Chinese policies, expertise and ideologies, as discussed above, into developing countries. China has gone from having very few investments in Cambodia, Laos and Myanmar to becoming all three countries' largest foreign direct investor [38]. From 2006 to 2011, China invested over $\$ 6.1$ billion into the three countries in their hydropower sectors alone [39] (See Figure 1 below). This figure is likely a low estimate as some concession agreements were signed but not counted during that time. Furthermore, it does not include the currently on hold Myitsone project in Myanmar valued at over \$3.6 billion USD.

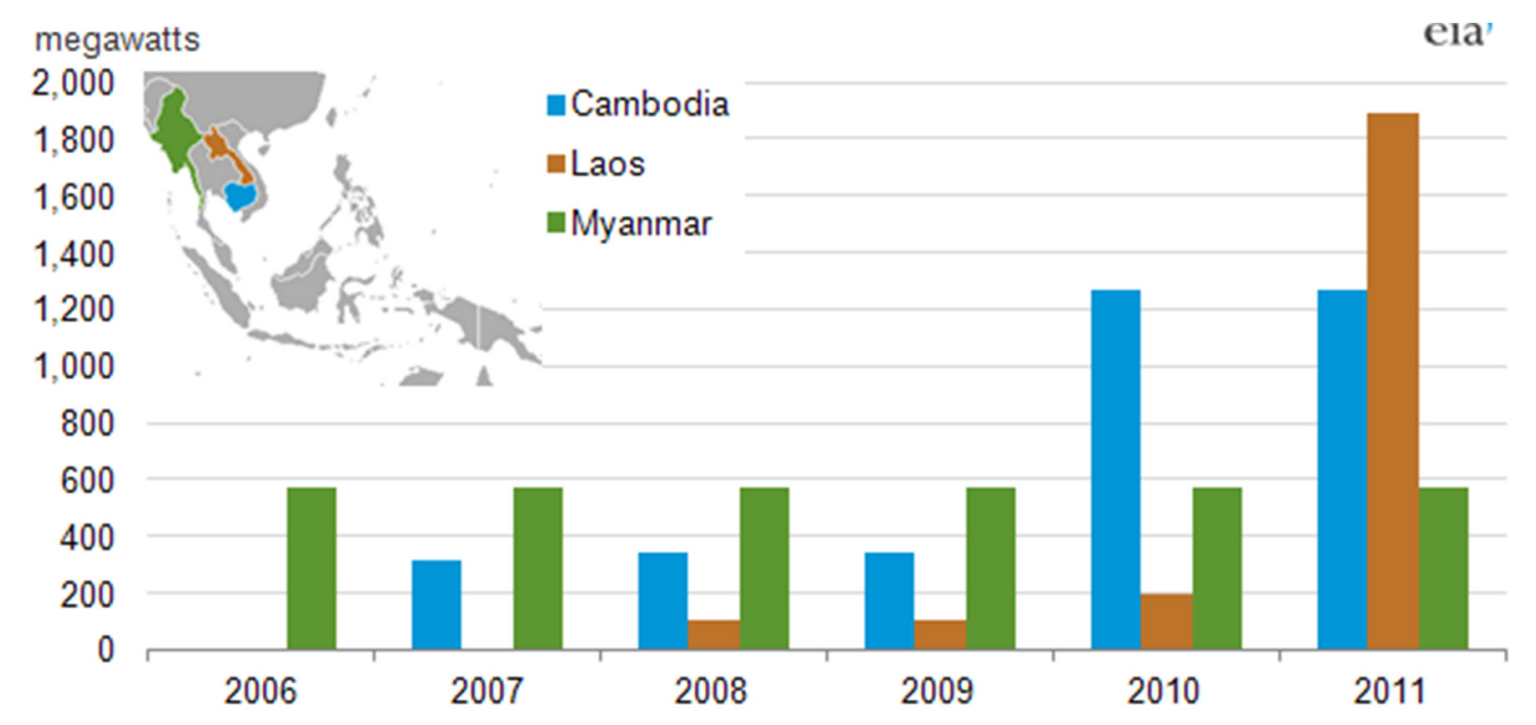

Figure 1. Cumulative hydroelectric capacity additions financed by China (2006-2011) (Source EIA, 2013 [39]).

When Chinese ideologies and policies that disregard or downplay connections and trade-offs across the nexus, as outlined in the narratives above, are exported to the LMB, there are potentially significant consequences for livelihoods, food security and the environment across the region. An example of how these policies, expertise and ideologies are exported can be seen in how Beijing's outward investment policies are mirrored in Lao PDR's hydropower sector. Chinese corporations had just two projects completed as of February 2015, for a combined $210 \mathrm{MW}$. However, there is $1010 \mathrm{MW}$ under construction, and $3892 \mathrm{MW}$ that have MOUs signed but have yet to begin construction, including three out of six of the dams planned for the Mekong mainstream. If all of these projects are realized, the scale of China's installed capacity within the Lao PDR will have increased nearly 25 times between 2015 and 2030 [7]. We argue that China's lack of recognition of trade-offs across the nexus has driven many of these hydropower projects to disregard or downplay the evidence of their impacts on fisheries, livelihoods and the environment $[7,40]$.

The scale of the projects that the Chinese are pursuing is also increasing as shown by Myanmar's hydropower climate. Chinese companies signed the contract for the Yeywa dam in 2005, finishing the construction of the $790 \mathrm{MW}$ project in 2011, making it the largest dam in the country. There are 46 dams planned from 2016 to 2030 with 12 of these over 1000 MW of installed capacity. Of these dozen 1000 MW plus projects, Chinese companies have 11, including the Mong Tong Dam, which is 7110 MW [41]. 
The potential and current negative implications of these investments across the nexus is significant [42-44]. Governments in Cambodia, Laos and Myanmar face major challenges in monitoring and regulating investment and its social and environmental impacts at this scale and speed [42-44]. The countries still have very young governments and judicial systems that are going through major institutional changes and improvements, but are currently not capable of holding large corporations accountable. In terms of transboundary impacts, different and often competing political and economic goals and historical and cultural issues compound opportunities for cooperation at the basin scale [45]. Transboundary water law also offers limited opportunities to challenge the transboundary impacts of upstream states on the water and food especially when legal frameworks across the basin states are based on different variables and rationales [46], and only Vietnam has signed up to the United Nations Watercourses Convention. An indication of the limitations and challenges of promoting good water governance and holding SOEs accountable can be seen in Transparency International's World Ranking indices as demonstrated in Table 2 [47-49].

Table 2. An overview of three international indices where China is heavily investing in hydropower in the GMS.

\begin{tabular}{cccc}
\hline Country & Ease of Doing Business Rating (Out of 189) & Corruption Index (Out of 177) & Freedom of Press (Out of 179) \\
\hline Cambodia & 137 th & 160 th & $143 \mathrm{rd}$ \\
Lao PDR & 159 th & 140 th & 168 th \\
Myanmar & $182 \mathrm{nd}$ & $157 \mathrm{th}$ & $151 \mathrm{st}$ \\
\hline
\end{tabular}

Cambodia, Lao PDR, and Myanmar have portrayed large-scale hydropower development as essential for their own economic development and their citizens' livelihood improvement [50,51]. However, there have been very little independent data or studies that directly equate large-scale dam construction in these countries to the improvement of livelihoods. The more realistic driving force behind the domestic government support for these projects is the need for capital through foreign direct investment (FDI). This FDI comes with key revenue opportunities for national governments generated through energy export to neighboring countries, primarily Thailand, that have much higher energy demands [52-54].

Chinese ODI in hydropower development in the GMS is often partly justified as supplying technology to developing countries or as an important strategy for China to increase its domestic energy supply and security. Despite this justification, China was a net exporter of energy to the region in 2010 [55]. In Lao PDR and Myanmar, the majority of the energy exported is destined for Thailand. There are no transmission lines from Cambodia to China, yet the Kingdom of Cambodia has recently begun an ambitious hydroelectric expansion with the help of Chinese SOEs.

Sinohydro completed construction of the country's first large-scale project, the Kamchay Dam, in 2011 [36]. Rather than having a vast array of small and medium projects (Lao PDR has more of this makeup), Cambodia is instead hosting a few large and controversial Chinese dam projects, including the Lower Sesan 2. These large-scale projects allow for greater injections of ODI into the Cambodian government and the scale and technical nature of the projects ensure that the Chinese companies involved will be central level SOEs.

Burgos and Sophal [56] argue that Hun Sen's relationship with China creates an opportunity for the country to develop its economy without conditional loans and grants from Western donors that may 
include calls for reform or restructuring of existing powerbases. Government-sanctioned projects give the Chinese SOEs political security and the ability to operate with greater autonomy in the country $[55,56]$. Examples of this can be seen in the Lower Sesan 2, where reservoir clearing began inside the concession area before dam designs were even approved [57]. The tree clearing at the Lower Sesan 2 was also illegal as it extended well beyond the borders defined in the concession agreement [58]. Many speculate that the central government and the SOEs are signing dam concession agreements in order to access the valuable timber reserves. The Ministry of Environment has the responsibility to hold SOEs responsible for producing and implementing Environmental Impact Assessments (EIAs) and Environmental Management Plan (EMPs). In the case of the Kamchay Dam, however, which was signed by Wen Jiabao and Hun Sen, construction went on for years without either an EIA or EMP [36].

Cambodia is China's most important political ally in the region and this relationship likely creates favourable conditions for Chinese SOEs operating in the country. In 2013, after ASEAN attempted to unite in its discussion with China over the South China Sea issues, Wang Yi, the Chinese foreign minister to Cambodia, refused to attend. Wang Yi explained in a statement to reporters that China is interested in protecting Cambodia from outside interests, hence his refusal to attend the ASEAN discussion [59]. As the main driver of the South China Sea tension is the potential undersea oil and gas reserves, it is possible to link China's interests in Cambodia back to China's domestic nexus. These examples demonstrate how hydropower investment can serve as a placeholder for larger political and economic issues that are not necessarily energy security or profit driven.

China is politically stronger in Cambodia than in the Lao PDR or Myanmar-the other two GMS nations where Chinese hydropower development is extensive. Chinese SOEs in Cambodia have a relatively large stake in the hydropower industry due to the scale of their projects and the lack of developer diversity in the sector. China has invested over $\$ 1.6$ billion in just six projects, with four now operational, and two expected to complete construction in 2015 [58]. The Chinese Chamber of Commerce in Cambodia is dominated by hydroelectric SOEs and the industry will likely continue to expand. China's political and economic strategy within the region and ASEAN, and the Cambodian government's dependence on Chinese investment highlight some of the drivers behind hydropower decision-making. The analysis also shows that individual projects do not necessarily need to be profitable to be approved, but rather contribute to grander relationship goals that are key for both governments and their political and economic strategies.

\section{Foreign Exchange Reserves as an Economic Driver of Investment}

One of the issues around Chinese ODI meriting greater attention is the link between large-scale infrastructure projects and China's vast foreign exchange reserves (forex). China's forex has increased tenfold over the past decade, reaching \$3.82 trillion at the end of 2013 [60]. This is by far the largest stockpile of forex in the world, three times that of the next largest held by Japan [61]. This large stock of forex threatens to cause the yuan to inflate, which in turn threatens China's export market and foreign investment. To prevent the yuan's inflation, China's central bank regulates fluctuations while purchasing large quantities of foreign reserves [62]. One of the main sources of foreign reserves are low-interest treasury bonds from the US and Japan, which can be as low as $2.8 \%$ over 10 years [61]. This huge 
amount of forex also makes China vulnerable to fluctuations in global forex markets, especially in instabilities of USD and JNY.

During the global economic recession both the U.S. and Japan responded to the crisis through monetary easing, or in other words, by aggressively running the printing presses, churning out cash, and devaluing their currencies. This concerns Beijing, which is sitting on huge sums of U.S. and Japanese forex while vast amounts of investment continue to flood into the country, threatening the yuan and therefore China's economic stability.

In order to alleviate these concerns, the Chinese banking system quickly pushes money out of the country to its SOEs in the form of ODI, and the easiest way to move large quantities of money outward is through large-scale infrastructure projects, such as hydropower dams. The Export-Import Bank of China (China Exim) is one of three policy banks that was established in 1994 along with the China Development Bank (CDB) and the Agricultural Development Bank of China. China Exim and CDB are the primary lenders for overseas investment in resource development. China Exim's mandate states that it is to "assist Chinese companies with comparative advantages in their offshore project contracting and outbound investment, and promote international economic cooperation and trade" [63]. In the last decade, China Exim's lending has increased dramatically and the bank is now the largest export credit agency in the world [64]. China Exim has been able to increase lending by $30 \%-40 \%$ year on year, fueling the ever expanding ODI under China's Going Global Strategy [64].

Long term payback systems are generally preferred by banks, which coincides well with large-scale hydropower projects where the Build Operate Transfer contract is usually a few decades in duration. Some of the large infrastructure projects carried out by SOEs might not be profitable, but this is inconsequential as the government has a mandate to spend money. Additionally, many of these concessional loans are attached to natural resource access [65]. Therefore, China's ODI into large-scale hydropower projects is not necessarily based on alleviating nexus pressures as its policies state, but can be seen as part of a strategy to ensure the country's greater economic security against global currency fluctuations that threaten the value of the RMB, and the depreciation of China's forex reserves.

\section{Conclusions}

This paper examined some of the key political and economic drivers behind Chinese SOEs' hydropower activities and the implications of these drivers on the recognition and management of nexus interconnections and trade-offs. Chinese SOEs are amongst the biggest players in global hydropower development and are heavily involved in dozens of projects across the Mekong Basin. The political economy approach used in this analysis reveals the forces that drive the pace, location and scale of this hydropower development both domestically in China and in the GMS. These forces include how hydropower projects are linked to bigger packages of trade and aid and FDI, which are important sources of revenue for developing countries such as Lao PDR, Myanmar and Cambodia. In addition, hydropower projects also provide a guise to access lucrative natural resources such as timber. Other key forces analyzed include the link between large-scale infrastructure projects and China's vast foreign exchange reserves, which facilitate SOEs to make hydropower investments abroad. The benefits of hydropower investments for both SOEs and domestic states are also linked to political alliances that have geopolitical dimensions. 
When the political economy and nexus approaches are combined, the analysis reveals some of the key drivers that cause narratives surrounding hydropower to downplay or disregard trade-offs and interconnections across water, energy and food. These narratives, which position hydropower as a win-win for both upstream and downstream states, are in contrast to hundreds of scientific studies that demonstrate the substantial trade-offs of hydropower development. Hydropower dams in the Mekong Basin have been shown to have significant negative impacts on livelihoods, food security and the hydrology and ecosystems of the Mekong River and its tributaries [7,42-44].

Hydropower development by SOEs in the Mekong Basin also has potentially important transboundary impacts across water and food [42-44]. Domestic and transboundary water law currently has limited influence to address these impacts. Lower Basin states are challenged by limited capacity and often weak and underfunded institutions to negotiate or manage large-scale impacts across the nexus. Furthermore, diverse political and economic goals and important cultural and historical differences have impended basin-wide cooperation surrounding mainstream dams despite the best efforts of the MRC [45].

Chinese SOEs' hydropower investments and activities are part of an increasing trend for both individual state and private sector led infrastructure financing and development that is expected to reach as much as four trillion dollars by 2017 [66-68]. The Asian Infrastructure and Investment Bank and the Silk Road Fund, for example, will soon bring an additional $\$ 140$ billion dollars of investment for development, a large proportion of which will be aimed at hydropower. By using a nexus and political economy approach this study provides a useful link to studies that examine impacts of hydropower development on water and food through its analysis of the drivers and implications of silo decision-making. Further research is needed to consider the opportunities and challenges the enormous investment by SOEs and the private sector will have on the interconnected spheres of water, energy and food.

\section{Acknowledgments}

We thank the anonymous reviewers and academic editors for their constructive comments that significantly helped to improve the paper. We also thank Juliet Lu for comments on an early draft.

\section{Author Contributions}

Nathanial Matthews coordinated the writing process of the article. He was mainly responsible for writing the introduction, method and conclusion. Stew Motta led the analysis in section three and four. Both authors contributed to the final writing of the piece.

\section{Conflicts of Interest}

The authors declare no conflict of interest.

\section{References}

1. Hoff, H. Understanding the Nexus; Background Paper for the Bonn2011 Conference: The Water, Energy and Food Security Nexus; Stockholm Environment Institute: Stockholm, Sweden, 2011.

2. Allouche, J.; Middleton C.; Gyawali, D. Technical veil, hidden politics: Interrogating the power linkages behind the nexus. Water Altern. 2015, 8, 610-626. 
3. Allouche, J.; Middleton, C.; Gyawali, D. Nexus Nirvana or Nexus Nullity? Adynamic Approach to Security and Sustainability in the Water-Energy-Food Nexus; STEPS Working Paper 63, STEPS Centre: Brighton, UK, 2014.

4. White, G.F.; deVries, E.; Dunkerley, H.B.; Krutilla, J.V. Economic and Social Aspects of Lower Mekong Development; Mekong Committee: Bangkok, Thailand, 1962.

5. Scott, C.A.; Kurian, M.; Wescoat, J.L. The water-energy-food nexus: Enhancing adaptive capacity to complex global challenges. In Governing the Nexus: Water, Soil and Waste Resources Considering Global Change; Kurian, M., Ardakanian, R., Eds.; Springer: Dordrecht, The Netherlands, 2014.

6. Lee, S. Benefit Sharing in Environmental Governance: Beyond Hydropower in the Mekong River Basin. In The International Handbook of Political Ecology; Bryant, R., Ed.; Edward Elgar: London, UK, 2015; p. 189.

7. Ziv, G.; Baranb, E.; Namc, S.; Rodríguez-Iturbed, I.; Levina, S. Trading-off Fish Biodiversity, Food Security, and Hydropower in the Mekong River Basin. Proc. Natl. Acad. Sci. USA 2012, 109, 5609-5614.

8. Smajgl, A.; Ward, J. The Water-Food-Energy Nexus in the Mekong Region: Assessing Development Strategies Considering Cross-Sectoral and Transboundary Impacts; Springer-Verlag: New York, NY, USA, 2013.

9. Foran, T. Node and regime: Interdisciplinary analysis of water-energy-food nexus in the Mekong region. Water Altern. 2015, 8, 655-674.

10. Dupar, M.; Oates, N. Getting to grips with the water-energy-food "nexus". Climate and Development Knowledge Network (London). Available online: http://cdkn.org/2012/04/getting-to-grips-withthe-water-energy-food-nexus (accessed on 10 July 2015).

11. Molle, F. Irrigation and Water Policies in the Mekong Region: Current Discourses and Practices; International Water Management Institute (IWMI) Research Report 095; IWMI: Colombo, Sri Lanka, 2005.

12. Hirsch, P. Water Governance Reform and Catchment Management in the Mekong Region. J. Environ. Dev. 2006, 15, 184-201.

13. Middleton, C.; Allouche, J.; Gyawali, D.; Allen, S. The rise and implications of the water-energy-food nexus in Southeast Asia through an environmental justice lens. Water Altern. 2015, 8, 627-654.

14. Middleton, C.; Allen, S. Asia Pacific Sociological Association Conference Paper. Available online:http://carlmiddleton.net/wp-content/uploads/2014/12/MiddletonAllan_Nexus_FINAL.pdf (accessed on 11 July 2015).

15. Mitchell, M. The Political Economy of Mekong Basin Development. In The Politics of Environment in Southeast Asia: Resources and Resistance; Hirsch, P., Warren, C., Eds.; Routledge: London, UK, 1998; pp. 71-89.

16. Verhoeven, H. The Nexus as a Political Commodity: Agricultural Development, Water Policy and Elite Rivalry in Egypt. Int. J. Water Resour. Dev. 2015, 1-15, 360-374.

17. China's 12th Five Year Plan (FYP). Available online:http:/www.britishchamber.cn/sites/ default/files/full-translation-5-yr-plan-2011-2015.doc (accessed on 20 November 2014).

18. Zhang, Q.; Xia, Q.; Clark C.K.L.; Shu G. Technologies for Efficient Use of Irrigation Water and Energy in China. J. Integr. Agric. 2013, 12, 1363-1370. 
19. Air pollution in China: A hazy future? Available online: http://sustainability-ranking. channelnewsasia.com/news-a-hazy-future.html (accessed on 5 November 2015).

20. Grumbine, E.; Xu, J. Recalibrating China's environmental policy: The next 10 years. Biol. Conserv. 2013, 166, 287-292.

21. Schuman, S.; Lin, A. China's Renewable Energy Law and Its Impact on Renewable Power in China: Progress, Challenges and Recommendations for Improving Implementation. Energy Policy 2012, 51, 89-109.

22. Wang, F.; Yin, H.; Li, S. China's Renewable Energy Policy: Commitments and Challenges. Energy Policy 2010, 38, 1872-1878.

23. Ma, B.; Zhou, S. Smart-grid policies: An international review. Wiley Interdiscip. Rev.: Energy Environ. 2013, 2, 121-139.

24. Magee, D. New Energy Geographies: Powershed Politics and Hydropower Decision Making in Yunnan, China. Ph.D. Thesis, University of Washington, Seattle, WA, USA, 2004.

25. Xinhua. China to Build Huge Power Station on Lancang-Mekong River. Available online: http://english.peopledaily.com.cn/200201/20/eng20020120_89013.shtml (accessed on 13 May 2014).

26. Mekong River Commission (MRC). Mekong River Commission and China Boost Water Data Exchange. Available online: http://www.mrcmekong.org/news-and-events/news/mekong-rivercommission-and-china-boost-water-data-exchange/ (accessed on 15 October 2014).

27. Liebman, A. Trickle-down Hegemony? China's "Peaceful rise" and Dam Building on the Mekong. Contemp. Southeast Asia 2005, 27, 281-304.

28. MRC. Remarks by H.E. Song Tao, Vice Minister of Foreign Affairs of the People's Republic of China. Available online: http://www.mrcmekong.org/news-and-events/speeches/first-mrc-summit-5/ (accessed on 16 May 2014).

29. Kummu, M.; Varis, O. Sediment-related Impacts Due to Upstream Reservoir Trapping, the Lower Mekong River. Geomorphology 2007, 85, 275-293.

30. Urban, F.; Nordensvärd, J.; Khatri, D.; Wang, Y. An analysis of China's investment in the hydropower sector in the Greater Mekong Sub-Region. Environ. Dev. Sustain. 2013, 15, 301-324.

31. McDonald, K.; Bosshard, P.; Brewer, N. Exporting Dams: China's Hydropower Industry Goes Global. J. Environ. Manag. 2009, 90, S294-S302.

32. Lee, J. State Owned Enterprises in China: Reviewing the Evidence. In OECD Working Group on Privatisation and Corporate Governance of State Owned Assets; OECD: Paris, France, 2009.

33. China's Outward FDI Reaches New Highs on Strong Growth in 2012-13. Available online: http://asiatoday.com.au/content/china\%E2\%80\%99s-outward-fdi-reaches-new-highs-strong-growth2012-13 (accessed on 5 November 2015).

34. Ministry of Commerce People's Republic of China (MOFCOM). Regular Press Conference of Ministry of Commerce on January 21 2015. Available online: http://english.mofcom.gov.cn/article/ newsrelease/press/201501/20150100878729.shtml (accessed on 18 June 2015).

35. MOFCOM (Ministry of Commerce of the People's Republic of China). Brief Statistics on China Direct Investment Overseas in 2013. Available online: http://english.mofcom.gov.cn/article/ statistic/foreigntradecooperation/201401/20140100464237.shtml (accessed on 2 June 2014).

36. Grimsditch, M. China's Investments in Hydropower in the Mekong Region: The Kamchay Hydropower Dam, Kampot, Cambodia; World Resources Institute: Washington, DC, USA, 2012. 
37. McNally, A.; Magee, D.; Wolf, A.T. Hydropower and Sustainability: Resilience and Vulnerability in China's Powersheds. J. Environ. Manag. 2009, 90, S286-S293.

38. Matthews, N.; Motta, S. China's Influence on Hydropower Development in the Lancang River and Lower Mekong River Basin; CPWF Mekong: Vientiane, Lao PDR, 2013.

39. EIA (Energy Information Administration).U.S. Energy Information Administration. Available online: http://www.eia.gov/todayinenergy/ (accessed on 2 June 2014).

40. Magee, D. The dragon upstream: China's role in Lancang-Mekong development. In Politics and Development in a Transboundary Watershed; Springer: Dordrecht, The Netherlands, 2012.

41. Electricite Du Laos (EDL). Power Development Plan of Lao PDR 2015-2025; Power Plant Development Department, Electricite Du Laos: Vientiane, Lao PDR, 2015.

42. Lu, X. X.; Li, S.; Kummu, M.; Padawangi, R.; Wang, J. J. Observed changes in the water flow at Chiang Saen in the lower Mekong: Impacts of Chinese dams? Q. Int. 2014, 336, 145-157.

43. Siciliano, G.; Urban, F.; Kim, S.; Lonn, P.D. Hydropower, social priorities and the rural-urban development divide: The case of large dams in Cambodia. Energy Policy 2015, 86, 273-285.

44. Orr, S.; Pittock, J.; Chapagain, A.; Dumaresq, D. Dams on the Mekong River: Lost fish protein and the implications for land and water resources. Glob. Environ. Chang. 2012, 22, 925-932.

45. Suhardiman, D.; Giordano, M.; Molle, F. Scalar disconnect: The logic of transboundary water governance in the Mekong. Soc. Nat. Resour. 2012, 25, 572-586.

46. Rieu-Clarke, A. Transboundary hydropower projects seen through the lens of three international legal regimes-Foreign investment, environmental protection and human rights. Int. J. Water Gov. 2015, 3, 1-24.

47. Greater Mekong Dams Database. CGIAR Program on Water, Land and Ecosystem's Greater Mekong Program; WLE: Vientiane, Lao PDR, 2015.

48. International Finance Corporation (IFC). Doing Business: Economy Rankings. Available online: http://www.doingbusiness.org/rankings (accessed on 2 June 2014).

49. Corruption Perceptions Index 2013. Available online: http://cpi.transparency.org/cpi2013/results/ (accessed on 2 June 2014).

50. Reporters without Borders (RWB). Press Freedom Index 2013. http://en.rsf.org/press-freedomindex-2013,1054.html (accessed on 2 June 2014).

51. Sokheng, V. Phnom Penh Post. Available online: http://www.phnompenhpost.com/national/pmhun-sen-ushers-new-dam (accessed on 2 June 2014).

52. Geheb, K.; West, N.; Matthews, N. The Invisible Dam: Hydropower and its narration in the Lao People's Democratic Republic. In Hydropower Development in the Mekong Region: Political, Socio-Economic and Environmental Perspectives; Matthews, N., Geheb, K., Eds.; Routledge: London, UK, 2014.

53. Matthews N. Water Grabbing in the Mekong basin-An Analysis of the Winners and Losers of Thailand's Hydropower Development in Laos. Water Altern. 2012, 5, 392-411.

54. Kattelus, M.; Rahaman, M.M.; Varis, O. Myanmar under Reform: Emerging Pressures on Water, Energy and Food Security. Nat. Resour. Forum 2014, 38, 85-98. 
55. Zhai, Y.; Jude, A.J. Energy Sector Integration for Low-carbon Development in the GMS: Towards a Model of South-South. In Greater Mekong Subregion: From Geographical to Socio-Economic Integration; Shrestha, O.L., Chongvilaivan, A., Eds.; Institute of Southeast Asian Studies: Singapore, Singapore, 2013, p. 216.

56. Burgos, S.; Sophal, E. China's Strategic Interest accessed in Cambodia: Influence and Resources. Asian Surv. 2010, 50, 615-639.

57. Cambodia's Hydropower Development and China's Involvement. Available online: https://www.internationalrivers.org/files/attached-files/cambodia_hydropower_and_chinese_ involvement_jan_2008.pdf (accessed on 5 November 2015).

58. Sovuthy, K. 2014. The Cambodia Daily. Available online: http://www.cambodiadaily.com/news/ lawmaker-blasts-illegal-logging-in-s-treng-59494/ (accessed on 2 June 2014).

59. Sothanarith, K. Voice of America. Available online: http://www.voanews.com/content/cambodiaurges-closer-asean-ties-with-china/1734944.html (accessed on 2 June 2014).

60. Xinhua. Global Times. Available online: http://www.globaltimes.cn/content/841301.shtml\#. UvxnMt9BH (accessed on 2 June 2014).

61. China's Forex Reserves Reach 3.82 Trillion USD. Available online: http://news.xinhuanet.com/ english/china/2014-01/15/c_133046451.htm (accessed on 2 June 2014).

62. McKinnon, R.; Schnabl, G. China's exchange rate and financial repression: The conflicted emergence of the RMB as an international currency. China World Econ. 2014, 22, 1-35.

63. Morrison, W.; Lebonte, M. China's Currency Policy: An Analysis of the Economic Issues. Available online: https://www.fas.org/sgp/crs/row/RS21625.pdf (accessed on 6 November 2015).

64. Islam, T.; Li. X. South-South Cooperation Policy and Practice by the Export Import Bank of China. IOSR J. Econ. Financ. 2014, 3, 9-19.

65. Tan, X. World Resources Institute. Available online: http://www.wri.org/blog/2011/06/emergingactors-development-finance-closer-look-chinese-and-brazilian-overseas (accessed on 2 June 2014).

66. Step Lightly: China's Ecological Impact on Southeast Asia. Wilson Center. Available online: http://www.wilsoncenter.org/publication/step-lightly-chinas-ecological-impact-southeast-asia (accessed on 2 June 2014).

67. Global Infrastructure Investment to Reach Four Trillion Dollars by 2017, Finds New Bain \& Company Study. Available online: http://www.bain.com/about/press/press-releases/globalinfrastructure-investment-to-reach-four-trillion-dollars-by-2017.aspx (accessed on 25 August 2015).

68. Merme, V.; Ahlers, R.; Gupta, J. Private Equity, Public Affair: Hydropower Financing in the Mekong Basin. Glob. Environ. Chang. 2014, 24, 20-29.

(C) 2015 by the authors; licensee MDPI, Basel, Switzerland. This article is an open access article distributed under the terms and conditions of the Creative Commons Attribution license (http://creativecommons.org/licenses/by/4.0/). 